the 14th day we descended precipitouslydriven by blizzards- to 11,000 feet $(3,344 \mathrm{~m})$. The diuresis promptly ceased and the specific gravity returned at once to normal. I met two climbers who were in the early stages of pulmonary oedema: in both there was oliguria with a high specific gravity (1.025 and 1.030).

Singh and others ${ }^{1}$ found that oliguria often heralds the onset of pulmonary oedema of mountains. Conversely, in those who seemed to be immune to the effects of altitude there is a diuresis on ascent. ${ }^{2}$ Urine osmolarity and altitude are sometimes related and excretion of protein rises with altitude. ${ }^{3}$ In subacute mountain sickness a high specific gravity is sometimes found." Diuresis induced by frusemide is very effective prophylaxis of pulmonary oedema of mountains. ${ }^{1}$ In subjects who are long acclimatized changes in specific gravity are in the normal range. ${ }^{2}$

Renal changes with altitude may not be due directly to hypoxia but to endocrine or possibly reflex atrial influences. ${ }^{1}$ Hypoxia causes considerable water flux between extracellular and intracellular compartments at first, ${ }^{5}$ perhaps by increasing capillary permeability. If not excreted by the continuous 24-hour diuresis I have described water excess may be a prime factor in precipitating oedema of the lung. Among various other factors could be pulmonary vein constriction or left ventricular failure, both directly due to hypoxia. The physiological picture is of course vastly more complicated, but the above may serve as a simple working hypothesis.-I am, etc.,

A. Pines

Ware, Hert:

1 Singh, I., et al., New England foumal of 2 Pugh, L. G. C. E., British Medical Yournal, 1962, 2, 621.

3 Rennie, I. D. B., and Joseph, B. J., Lancet, 1970, $1,1247$.

and Sport Vol, and Lundberg, Exercise and Alitirude, Medicine Shields, J. L. Jokl, p 117. Basel, Karger, 1968. Terrestrial Eklevations, ed. A. H. Hegnauer, p. 24, U.S. Army Research Institute of
vironmental Medicine, Natick, Mass. 1969.

\section{College of Anaesthetists}

SiR,-The excellent document of information circulated with the referendum on collegiate formation from the Association of Anaesthetists (see 19 August, p. 483, and 26 August, p. 528) was overtaken by events when describing national representation.

On 13 July the Central Committee for Hospital Medical Services decided that the B.M.A. Anaesthetists Group and its committee should be abolished at its own request (Supplement, 5 August, p. 129) and that there should be substituted a standing subcommittee consisting of those anaesthetists, both junior and senior, serving on the C.C.H.M.S., the B.M.A. Council, and the Central Manpower Committee, together with an equal number appointed by the Association of Anaesthetists, with certain groups, for example, juniors, represented as of right, while the seat on the C.C.H.M.S formerly held by the B.M.A. group would be allocated to the subcommittee. These propo-als were approved in principle by the B.M.A. Council on 22 July.

I believe that this standing committee will fulfil the criteria sought by Dr. D. W. Barron and others (19 August, p. 468) in providing a single political voice for the specialty, without involving either the Faculty or a college. Indeed, a single autonomous body would, as Professor Cecil Gray so rightly points out (26 August, p. 528), lose its claim to charitable status if it were to embrace both academic and political functions. While Sir Paul Chambers in his report on the B.M.A. states "that, while there must be adequate provision for co-ordination at a higher level, separate fields"-for example, organization or conditions of service, "should be the subject of handling by separate committees ... (with no common membership)."

I must again agree with Professor Gray on finance. The establishment of a separate college with even modest facilities for research, examinations, and organization would today cost perhaps a couple of million pounds, between say 20,000 Fellows. Many anaesthetists must wonder what the examination and membership fees would need to be? In 1973 we shall enter the E.E.C., a community where anaesthesia as distinct from surgery is by no means as well established or represented as here. I cannot personally imagine a worse time to contemplate hiving off from an established college, which, as Sir Thomas Holmes Sellors says in his last presidential Newsletter, "can speak with an effective voice which must be both coherent and united."-I am, etc.,

Hythe, Kent

E. B. LEwIS

\section{Pimozide}

SIR,-Recently three of our patients had epileptiform seizures which were unexpected and difficult to explain. None had had fits previously and none was receiving known epileptogenic drugs. The one unusual feature they had in common was that they had recently been on pimozide and the dosage had been reduced or stopped. The intervals between reduction in dosage and the first fit were 31 days and 13 days. The interval between dose alteration and fit is long but the drug is claimed to have a prolonged action. There may be no direct causal relationship, but if there is it is one that may be missed because of the long interval.

The makers and the Committee on Safety of Medicines have been informed and fuller details furnished to the latter.-We are, etc.,

E. A. Burritt Darlington Memorial Hospital,

Darlington, Michael FaUlkarer Darlington,

\section{Misleading Prospectuses}

SIR,-On two occasions in the past week I have made very long and inconvenient journeys to be interviewed for some of the new consultant posts in accident departments. On each occasion the prospectus for the post appeared to be most attractive, with access to beds, intensive care units, and so on-in fact, posts which would be most satisfying to an enthusiastic doctor.

After the first interview we waited $1 \frac{1}{2}$ hours on'y to discover that the conditions of the job had been changed and that all the attractive aspects with -rawn. This made it quite unacceptable. The second inter- viewing committee, which contained some of the same members as the first, at least decided before the interview that these opportunities would not be available, so we were only an hour late beginning and I was able to withdraw without wasting too much time. One of the communications describing the post stated: "An initial allocation has been made of these resources [that is, beds, theatres, and intensive therapy unit] as a concrete indication of the intention of the Management Committee and medical staff to make a success of this appointment."

I feel that I must write to warn people applying for some of these posts about this misdescription. Several of those interviewed were brought long distances unnecessarily. When one has been applying for senior medical posts for some time one gets used to rudeness from regional boards, and some do not even bother to reply to applications for consultant posts, but this is a new departure, in my experience, and unless such habits are publicised they will probably get worse rather than better.-I am, etc.,

\section{W. B. S. LOOSMORE}

Oldham

Lancs

\section{Overpopulation}

SIR,-Your leading article discussing the fifth report from the Select Committee on Science and Technology (19 August, p. 432) ends thus: "When does a populated place become overpopulated? By what criteria is it judged to be so? These are questions that are rarely asked or answered in precise terms. A clear discussion of them from the medical profession is overdue." Surely, however, "clear discussion" of these questions has been in progress in the medical profession at least since 8 January when, as the result of a letter in the B.M.F. (8 January, p. 108) and in the Lancet, the Doctors and Overpopulation Group was formed. This now has over 1,500 members.

Such discussion can, I submit, be "clear" without the precision mentioned in the penultimate sentence quoted above. Inferring the population trends is indeed like "dodging after a hare"-there are too many uncontrolled variables for numerical precision in the estimates. But hair-splitting about exact numbers should not divert attention from the following incontrovertible facts: (1) No current estimate suggests a decrease in the population of the British Isles-all predict an increase of some millions. Only the precise number of millions is in doubt. (2) No previous estimate of stabilization or of a fall in U.K. numbers has ever been realized; there has been an annual increment, it seems, ever since the Black Death. (3) All other countries are likewise still increasing by variable amounts each year (though a very few are now approaching a net reproduction rate of unity). (4) The impact on the environment of each new birth (in excess of the replacement number) in developed countries such as this is many times greater than that in a country such as India-this because of a far higher rate of consumption of resources of all kinds and associated pollution. Harmful (non-recycling) technology and continued economic growth must also be controlled, as recently shown by the Club of Rome's computer study at the Massachusctts Institute of Technology.1 But as doctors we must not let the resnonsibilities of industrialists and politicians blind us to our own in the area of birth control. (5) A three-week dock strike has recently served as a sharp reminder of our great 